\title{
THE QUALITY OF WORK LIFE: A STUDY IN A TRANSPORTATION COMPANY
}

\author{
Julia Martins de Brito ${ }^{1}$, Paulo Lourenço Domingues Júnior ${ }^{2} \bowtie$, Jorge Alberto Veloso Saldanha ${ }^{3}$ \\ ${ }^{1}$ Undergraduate student in Administration at the Federal Rural University of Rio de Janeiro (UFRRJ), Brazil \\ ${ }^{2} \mathrm{PhD}$ in Sociology from the University of São Paulo and associate professor at the Federal Rural University of \\ Rio de Janeiro (UFRRJ), Brazil. \\ ${ }^{3}$ Graduated in Administration from Universidade Federal de Santa Catarina (UFSC/1999), Master in \\ Administration from UFSC/2004, PhD in Production Engineering from UFSC/2009. Associate Professor - II, \\ Federal Rural University of Rio de Janeiro (UFRRJ), Brazil
}

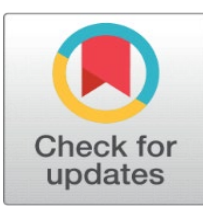

Received 17 September 2021

Accepted 17 October2021

Published 31 October2021

\section{CorrespondingAuthor}

Paulo Lourenço Domingues Júnior, pldominguesjr@uol.com.br

DOI

10.29121/granthaalayah.v9.i10.2021 .4333

Funding: This research received no specific grant from any funding agency in the public, commercial, or not-for-profit sectors.

Copyright: (C) 2021 The Author(s). This is an open access article distributed under the terms of the Creative Commons Attribution License, which permits unrestricted use, distribution, and reproduction in any medium, provided the original author and source are credited.

\section{ABSTRACT}

The object of this article is related to QWL (Quality of Life at Work) from the point of view of workers in a transport and tourism company in the interior of Rio de Janeiro. It had as problematic the factors that impact the Quality of Life linked to the work environment, workload, remuneration and benefits policies, as well as those related to the individual's family life and professional performance, among others. The general objective of the research was to understand which factors impact QWL and differentiate the positive and negative factors that impact this quality of life, in addition to contributing to improving QWL in the organization studied. A qualitative and exploratory research was carried out, through interviews with questions composed by the employee's profile and also open questions about QWL. It was concluded that the company needs to better identify the factors that contribute to the achievement and development of employees, and mainly, implement the suggestions for improvement indicated in the survey in order to achieve greater employee satisfaction with work and with their quality of life.

Keywords: Quality of Work Life (QWL), Collective Transport, Transport Company

\section{INTRODUCTION}

Currently, organizations have gone through transformations due to the demands of consumer markets and the competitiveness among companies. This scenario changed the dynamics of the business environment, in which the effort to survive demands greater productivity and more quality to meet market demands.

According to Timossi et al. (2010), the quality of life at work (QWL) emerges as an organizational strategy to help and contribute to organizations adapting to the dynamic environment in which they operate.

Thus, QWL influences the performance and productivity of employees, and the company must understand that a motivated employee brings positive results for the organization. Therefore, managers must be concerned with the worker's well-being and observe the needs for improvement in the work environment, aiming to combine productivity with employee satisfaction Oliveira et al. (2018).

The research problem of this study seeks to answer the following question: What factors impact the Quality of Work Life related to the work environment, workload, compensation and benefits policies regarding the individual's family life 
and, consequently, on professional performance?

This paper aims to understand which factors impact the Quality of Life at Work (QWL) from the point of view of workers in a transport company, differentiating the positive and negative factors that impact the quality of life at work; analyzing the results of the field research and contributing to the improvement of the impacts on the quality of life at work.

\section{THEORETICAL FRAMEWORK \\ 2.1. ORIGIN AND CONCEPT OF QUALITY-OF-LIFE AT WORK}

Some authors argue that studies on QWL began with the research by British scientist Eric Trist on worker satisfaction in the 1950s and covered the dimensions of the individual, work and organization Rodrigues (1998), Machado et al. (2018). In the mid-1960s, research on the subject intensified, due to the need for American businessmen to understand and influence the worker's relationship with work.

But the main theories and models about QWL were developed between the 1970s and 1980s and their concepts are used as a foundation for research until today. During this period, studies emerged with the aim of defining the ways in which QWL favors employees and organizations Garcia (2010).

For Marques (2021), the concept of Quality of Life at Work deals with specific actions aimed at continuous improvement of a company's technological, strategic, operational and human processes. In practice, it means offering employees better working conditions, a more harmonious environment that favors the development of the professional while performing their work functions.

The concept of quality of life at work or QWL, therefore, refers to the set of actions in the work environment, with the objective of making improvements to the daily lives of employees, thus increasing productivity and generating a climate of satisfaction by each employee within the organization.

\subsection{THE IMPORTANCE OF PEOPLE IN AN ORGANIZATION}

For Santos (2010), companies were concerned with production, that is, efforts were focused on the amount produced to increase market share, that is, the professional was just one element in the production process. Working conditions were precarious with long daily hours, often due to inhumane treatment that caused frequent accidents seen naturally by those who worked.

According to Ribeiro and Santana (2015), this scenario is constantly changing, as it considers the importance of people for the functioning of organizations, and it can be said that without the work, energy, dynamics, intelligence, creativity and rationality of people, organizations would not exist.

Also, according to Ribeiro and Santana (2015), employees spend a good part of their lives within organizations seeking to achieve their personal and individual goals, a factor of interdependence between people and the organization, that is, part of people's lives is occupied by work, representing for them human growth and professional satisfaction.

However, this view may often not be so recurrent and in some sectors, even the understanding of how the relationship between work and the quality of life of employees takes place is not clearly understood. 


\subsection{STRESS IMPACTS THE QUALITY-OF-LIFE AT WORK}

Studying work-related stress helps to understand the meaning of work and the quality of work life. From this perspective, there are several models and ways to study work-related stress Boas (2017)

According to Kurogi (2008), companies seek to carry out actions to achieve both organizational and workers' goals, as the organization, work relations and the worker have a permanent interdependence, thus, quality of life projects emerge in the organizations, emphasizing worker welfare. Given the constant changes in the world of work arising from technology, the innovation of products and services and the competitiveness between organizations, the stress level of workers has increased.

According to Conte (2003), the importance of QWL lies in the fact that the worker spends about 8 hours or more a day in the work environment, for at least 35 years of life. This characteristic of work becomes stressful as time passes and the worker realizes that there are no conditions or possibilities to make improvements. Human beings want to obtain quality of life and seek what can provide well-being and a satisfying life.

\subsection{POSITIVE FACTORS OF QUALITY-OF-LIFE AT WORK}

A pleasant environment is one that is concerned with the health and well-being of employees by valuing the human being, creating development opportunities, providing capabilities and potential (MORAES, 2010).

A suitable work environment is of paramount importance for the well-being of professionals. Without it, the company will likely never be able to retain its talent, serve customers well, or stand out from the competition. By generating quality of life, the company becomes much more productive, profitable and attractive.

Walton cited by Dias (2018) deals with fair and adequate Compensation, in which this criterion aims to measure QWL, through an adequate remuneration for the work performed. Benefits such as food stamps, health plan, dental plan, uniform, school assistance, etc. are included. This remuneration is also compared to the remuneration of colleagues and the labor market.

\section{METHODOLOGY}

It is intended to carry out as a methodology, the academic survey, using a qualitative approach in terms of nature and exploratory in terms of the research objectives. The research is based on bibliographic theoretical references and on the bases of articles from Scielo, Spell and ANPAD, specialized magazines, books and electronic pages on the subject, as well as materials and content on the history of the company studied.

After this initial phase, the exploratory research was carried out through the application of an interview consisting of the interviewee's profile and four open questions about theoretical and practical aspects of Quality of life at work with those experienced by employees in the company for the construction of the study.

The purpose of this work is to analyze the quality of life at work from the point of view of the internal workers of the public transport company, avoiding a priori use of theories that establish which factors impact the Quality of Life at Work.

Based on the consent of the professional and the completion of the interview in one copy, the structured instrument used for data collection was applied. 
Identification referring to the profile, investigating data: name, age, gender, number of children, marital status, length of work experience, length of experience in the company, function and title, position and weekly workload.

\section{RESEARCH RESULTS}

The company currently has 31 internal employees (administrative sector) at the headquarters in Três Rios. The sample consisted of 13 employees, representing approximately $42 \%$ of the company's employees, including females and males. Respondents agreed to participate in the survey voluntarily and not confidentially.

\subsection{AGE AND GENDER}

Regarding the age of respondents, $54 \%$ are between 16 and 24 years old, $15 \%$ are between 25 and 35 years old and 31\% are between 36 and 45 years old.

Regarding gender, $54 \%$ of respondents are male and $46 \%$ woman.

\subsection{CHILDREN AND MARITAL STATUS}

When asked about having children or not, 8 employees responded that they do not have children and are single, and 5 employees responded that they have children and are married. It was not possible to identify a correlation between the profile presented and the factors found.

\subsection{WORK EXPERIENCE TIME}

It is noticed that the company has a young profile. Regarding the experience of respondents, 7 (seven) have between 0 to 5 years, making up 54\%, followed by $23 \%$ who have more than 20 years of work experience, $15 \%$ who have 16 to 20 years and $8 \%$ who are 6 to 10 years old.

\subsection{TIME IN THE COMPANY}

It can be concluded that turnover within the surveyed company is low, since most employees analyzed have been in the organization for more than 5 (five) years. From 0 to 5 years in the company they have 9 (nine) employees, from 10 to 15 years 2 (two) employees and 1 (one) employee from 6 to 10 years and more than 20 years of time in the company.

\subsection{POSITIVE FACTORS OF QWL}

When asked about the positive factors of QWL found in the company, the most cited were the work environment, interpersonal relationships and benefits (meaning food card, health plan and transportation voucher. In addition, they were cited as positive factors for QWL, autonomy in activities, good salary and flexibility.

Factors such as working with satisfaction, receiving a salary on time, receiving benefits, having comfort, having equipment in perfect condition, respect for the employee, working with satisfaction, professional fulfillment and valorization, job and salary plan, good interpersonal relationships, cleanliness were mentioned. and hygiene, clear and effective communication, mutual trust, health plan, commitment, continuous improvement, productivity without overload, excellence in the execution of tasks, pleasant working conditions, continuous improvement of 
processes, conditions for professional development, good company performance, improvements in the work environment and professional recognition.

Nowadays, workers are looking for better working conditions, making an effort to study, in order to achieve professional growth, that is, better placements in the labor market and as they are qualifying, they increasingly want a return, whether for better conditions jobs, better wages, rewards and benefits.

When related to benefits, it is understood that the health plan, the food card and the transportation voucher are of great importance.

\subsection{QWL NEGATIVE FACTORS}

When asked about the negative factors of QWL found in the company, the most cited were ineffective communication, lack of professional development, lack of job and salary plan, furniture in poor condition and non-compliance with deadlines.

The negative factors that impact QWL mentioned by the interviewees were lack of commitment, furniture in poor conditions of use, lack of professional development, lack of job and salary plan, self-responsibility, pressure without coordination, overload, non-compliance with deadlines, ineffective communication, disorganization, lack of process management, lack of professional development, benefit deducted from salary, difference between old and new employees.

Without a doubt, communication has a strong influence on the way professionals relate internally. The lack of dialogue, a result of ineffective communication, leaves employees without guidance, which favors errors in tasks and internal conflicts.

Professional valuation are the measures taken by the organization in order to value, honor and encourage the work of employees. People management instruments such as recognition, culture and organizational climate initiatives are also related to this concept.

The lack of a job and salary plan in the company generates indefinite salaries, promotions or qualifications. It can affect the organizational climate and generate management and behavioral problems that harm the team and consequently the company.

Another factor mentioned was in relation to the furniture in the place, which is in poor condition, which reveals a certain lack of concern with the worker's ergonomic health.

And last but not least, non-compliance with deadlines was mentioned, which is a reflection of the professionals' lack of commitment to the company, which may be the result of lack of motivation.

\subsection{SUGGESTED IMPROVEMENTS}

In the search for improvement, QWL programs help in the worker's quality of life, within the limits of resources available by the company, making the work environment favorable to the employee. Regarding the suggestions for improvements mentioned by employees, it is possible to observe the clear and effective communication answered by $71 \%$ of the employees interviewed and $29 \%$ the professional appreciation.

Improving communication must consider leadership commitment. Superiors need to learn to democratize information to their subordinates, always keeping them informed of what is needed. Improving issues such as lighting, acoustics and 
temperature in the workspace, in addition to the ergonomics of office furniture, is a way to make the work environment pleasant.

\section{CONCLUSION}

Through the literature review and analysis of the results of interviews with professionals from the studied company, it was possible to understand the general objective of which factors impact the Quality of Work Life (QWL) from the workers' point of view and as specific objectives to differentiate the factors positive and negative impacts that impact the quality of life at work, contributing to the improvement of the impacts on the quality of life at work.

In order to alleviate or settle the existing problem, improvements are suggested, such as carrying out effective Human Resources policies. This is the sector responsible for implementing the QWL proposals and the main goal of the QWL program is the conciliation of the interests of individuals and organizations, that is, by improving worker satisfaction, the company's productivity is improved.

In this study, it can be highlighted that QWL can contribute to a better quality of life at work and in personal life. With its involvement, the company offers workers adequate work planning, recognizing the limitations of employees, and a healthy and safe environment in which to work. On the other hand, the employee feels motivated, satisfied and productive for the company. An efficient incentive program needs to contemplate three fundamental aspects: motivation; recognition and retribution (or reward).

In general, it is possible to conclude that the organization satisfies its employees in some factors, such as professional growth, interpersonal relationships, flexibility, favorable work environment, good salary, benefits, autonomy in activities, but it does not satisfy with furniture in poor condition of use, lack of professional development, lack of job and salary plan, self-responsibility, uncoordinated pressure, overload, non-compliance with deadlines, disorganization, lack of process management, non-compliance with deadlines, lack of professional development, benefit deducted from salary, difference between old and new employees and ineffective communication.

\section{REFERENCES}

Boas, Ana Alice Vilas; (2017) Morin, Estelle M. Qualidade De Vida No Trabalho: Um Modelo Sistêmico De Análise. Revista Administração Em Diálogo-Rad, V. 19, N. 2, P. 62-90. Retrieved from https://doi.org/10.20946/rad.v19i2.31720

Conte, Antonio Lázaro. (2003) Qualidade De Vida No Trabalho. Revista Fae Business, V. $7, \quad$ P. 32-34. Retrieved from https://d1wqtxts1xzle7.cloudfront.net/46008045/rev_fae_business_07_20 03_gestao_10QVT-with-cover-page-

v2.pdf?Expires=1637040048\&Signature=YKzN86RZ17ingbht1t6G fJoJ0Hr Cm WgW6qyXhA-

rRvc720tKhLY9AdDi1VoayrwoerDSOYvwXDZa2XnF3ESveJJEfHcoailhaAjq ugFIc62Ix62FtnKVgg69elwsFrEMgE5q2ablCg3qMFeRkOXx7HvIP7oYUEb3 t1zfFH7uhi3tyFM7HHfZAC2DZgOLY4Kc9WCcTTwJRZXASeriGZ7qBKgRMA zrBn DQ4vq6Rx1St6NmxDFJ2x7gm4q 0fQuBUegmhNJuQ0f4ytNaeTRoD 3eZGnnuS5TfV799kF0zLUttifY3cZdLZQbTBs9YBKfc8-

wT2qVe0GD3RGhbDnmS7Q_\&Key-Pair-Id=APKAJLOHF5GGSLRBV4ZA

Dias, Corintha. Investigação Sobre (2018) A Contribuição Da Saúde E Segurança Do Trabalho $\mathrm{Na}$ Qualidade De Vida Do Trabalhador: Um Estudo Com 
Profissionais Da Área De Sst Na Indústria De Alimentos Da Região De Pelotas/Rs. Tese De Doutorado. Universidade Federal De Pelotas.

Garcia, Edilene De Oliveira Pereira. (2010) O Conteúdo Significativo Da Qualidade De Vida No Trabalho Para Funcionários Públicos De Uma Secretaria De Saúde. Revista Eletrônica Gestão E Serviços, V. 1, N. 1, P. 76-94. Retrieved from https://doi.org/10.15603/2177-7284/regs.v1n1p76-94

Kurogi, Marcia Sumire. (2008) Qualidade De Vida No Trabalho E Suas Diversas Abordagens. Revista De Ciências Gerenciais, V. 12, N. 16, P. 1. Retrieved from https://revista.pgsskroton.com/index.php/rcger/article/view/2642

Machado, Paulo Roberto Silveira Et Al. (2018) A Qualidade De Vida No Trabalho Como Estratégia De Gestão De Pessoas: 0 Caso De Uma Indústria Gráfica De Santa Catarina. Sistemas \& Gestão, V. 13, N. 4, P. 532-540. Retrieved from https://doi.org/10.20985/1980-5160.2018.v13n4.1451

Marques, José Roberto. (2021) Conceito De Qualidade De Vida No Trabalho. Disponível Em. Retrieved from $<$ Https://Www.Jrmcoaching.Com.Br/Blog/Conceito-De-Qualidade-DeVida-No-Trabalho/.> Acessado Em 27 De Ago. 2020

Oliveira, Leandro Divino Miranda Et Al. (2018) Análise Da Satisfação Da Qualidade De Vida No Trabalho Em Uma Marmoraria Do Pontal. Ituiutaba/Mg. Brazilian Journal of Development, V. 4, N. 2, P. 655-669. Retrieved from https://www.researchgate.net/profile/Leandro-Oliveira-

26/publication/341655094_Analise_da_satisfacao_da_qualidade_de_vida_n o_trabalho_em_uma_marmoraria_do_Pontal/links/5ecd7e9e299bf1c67d20 1764/Analise-da-satisfacao-da-qualidade-de-vida-no-trabalho-em-umamarmoraria-do-Pontal.pdf

Ribeiro, Larissa Alves; Santana, Lídia Chagas De. (2015) Qualidade De Vida No Trabalho: Fator Decisivo Para 0 Sucesso Organizacional. Revista De Iniciação Científica-Ric Cairu, V. 2, N. 02, P. 75-96. Retrieved from https://www.cairu.br/riccairu/pdf/artigos/2/06_QUALIDADE_VIDA_TRA BALHO.pdf

Rodrigues, Marcus Vinícius Carvalho. (1998) Qualidade De Vida No Trabalho: Evoluçäo E Análise No Nível Gerencial. 4 Ed. Petrópolis, Rj: Vozes. Retrieved from https://pesquisa.bvsalud.org/portal/resource/pt/lil-165533

Santos, Flávia Arruda Dos. (2010) Qualidade De Vida No Trabalho: Benefício Para Empresa E Para Trabalhador. 35 F. Trabalho De Conclusão De Curso. Universidade Candido Mendes, Rio De Janeiro, 2010.

Timossi, Luciana Da Silva Et Al. (2010) Análise Da Qualidade De Vida No Trabalho De Colaboradores Com Diferentes Níveis De Instrução Através De Uma Análise De Correlações. Produção, V. 20, N. 3, P. 471-480. Retrieved from https://doi.org/10.1590/S0103-65132010005000031 